\title{
Synthesis of new N,N'-bis[1-aryl-3-(piperidine-1- yl)propylidene]hydrazine dihydrochlorides and evaluation of their cytotoxicity against human hepatoma and breast cancer cells
}

Kaan Kucukoglu, H. Inci Gul, Rengul Cetin-Atalay, Yosra Baratli, Anne-Laure Charles, Murat Sukuroglu, Mustafa Gul \& Bernard Geny

To cite this article: Kaan Kucukoglu, H. Inci Gul, Rengul Cetin-Atalay, Yosra Baratli, Anne-Laure Charles, Murat Sukuroglu, Mustafa Gul \& Bernard Geny (2014) Synthesis of new N,N'-bis[1-aryl-3(piperidine-1-yl)propylidene]hydrazine dihydrochlorides and evaluation of their cytotoxicity against human hepatoma and breast cancer cells, Journal of Enzyme Inhibition and Medicinal Chemistry, 29:3, 420-426, DOI: 10.3109/14756366.2013.795562

To link to this article: http://dx.doi.org/10.3109/14756366.2013.795562

Џll Article views: 180

View Crossmark data ¿
Published online: 16 Jul 2013.

曲 Published online: 16 Jul 2013.
Submit your article to this journal $\sqsubset$

Q View related articles ¿

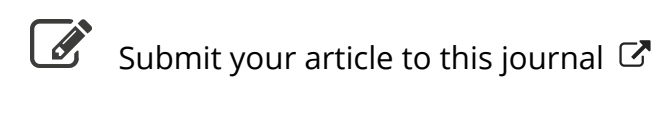

Citing articles: 5 View citing articles ¿ 


\title{
informa
}

healthcare

\section{Synthesis of new N,N'-bis[1-aryl-3-(piperidine-1-yl)propylidene] hydrazine dihydrochlorides and evaluation of their cytotoxicity against human hepatoma and breast cancer cells}

\author{
Kaan Kucukoglu ${ }^{1}$, H. Inci Gull ${ }^{1}$, Rengul Cetin-Atalay ${ }^{2}$, Yosra Baratli ${ }^{3}$, Anne-Laure Charles ${ }^{3}$, Murat Sukuroglu ${ }^{4}$, \\ Mustafa Gul ${ }^{5}$, and Bernard Geny ${ }^{3}$ \\ ${ }^{1}$ Department of Pharmaceutical Chemistry, Faculty of Pharmacy, Ataturk University, Erzurum, Turkey, ${ }^{2}$ Department of Molecular Biology and \\ Genetics, Bilkent University, Ankara, Turkey, ${ }^{3}$ Université de Strasbourg, Fédération de Médecine Translationnelle, Faculté de Médecine, Strasbourg, \\ France, ${ }^{4}$ Department of Pharmaceutical Chemistry, Faculty of Pharmacy, Gazi University, Ankara, Turkey, and ${ }^{5}$ Department of Physiology, \\ Faculty of Medicine, Ataturk University, Erzurum, Turkey
}

\begin{abstract}
$\mathrm{N}, \mathrm{N}^{\prime}$-Bis[1-aryl-3-(piperidine-1-yl)propylidene]hydrazine dihydrochlorides were synthesized by the reaction of 2 mols of 1-aryl-3-(piperidine-1-yl)-1-propanone hydrochlorides with $1 \mathrm{~mol}$ of hydrazine hydrate. Aryl part was $\mathrm{C}_{6} \mathrm{H}_{5}(\mathbf{P 1}), 4-\mathrm{CH}_{3} \mathrm{C}_{6} \mathrm{H}_{4}(\mathbf{P 2}), 4-\mathrm{CH}_{3} \mathrm{OC}_{6} \mathrm{H}_{4}(\mathbf{P} 3), 4-\mathrm{HOC}_{6} \mathrm{H}_{4}(\mathbf{P} 4)$, 4- $\mathrm{ClC}_{6} \mathrm{H}_{4}(\mathbf{P 5}), 3-\mathrm{CH}_{3} \mathrm{OC}_{6} \mathrm{H}_{4}(\mathbf{P 6}), 4-\mathrm{FC}_{6} \mathrm{H}_{4}(\mathbf{P 7})$ and $4-\mathrm{BrC}_{6} \mathrm{H}_{4}$ (P8). Except P1, all compounds were reported for the first time. The chemical structures were confirmed by UV, ${ }^{1} \mathrm{H} N M R,{ }^{13} \mathrm{C} N M R$ and HRMS spectra. P1, P2, P7 and P8 against human hepatoma (Huh7) cells and P1, P2, P4, P5, P6, P7 and P8 against breast cancer (T47D) cells have shown cytotoxicity. P1, P2 and P7 had more potent cytotoxicity against Huh7 cells than the reference compound 5-FU, whereas only P2 was more potent than the 5-FU against T47D cells. Representative compound P7 inhibited the mitochondrial respiration at 144, 264 and $424 \mu \mathrm{M}$ concentrations dose-dependantly in liver homogenates. The results suggest that P1, P2, P7 and P8 may serve as model compounds for further synthetic studies.
\end{abstract}

\section{Introduction}

Hepatocellular carcinoma (HCC) is the fifth most common neoplasm in the world and it ranks at third place in the list of cancer-related mortality ${ }^{1,2}$. As HCC is usually asymptomatic in the early stages, it is diagnozed at an advanced stage ${ }^{3,4}$. Furthermore, for most patients with HCC, surgery is the only curative treatment procedure, because HCC cells have high resistance to chemotherapeutic agents, so treatment options of HCC is very limited ${ }^{5}$. On the other hand, breast cancer is the leading cause of cancer death among women with approximately a million new cases each year ${ }^{6}$. Despite some therapy options such as surgery, chemotherapy, endocrine and radiation therapy in the treatment of breast cancer, several side effects and drug resistance to chemotherapeutic agents are often encountered problems in the course of therapy ${ }^{7}$. Therefore, it is necessary to develop novel approaches and discover new drug candidates that can be used in the treatment of HCC and/or breast cancer.

Mannich bases are synthesized by using a compound containing a reactive hydrogen atom, formaldehyde and a secondary amine in general. This process is known as the Mannich reaction ${ }^{8}$. They have various biological activities such as cytotoxic ${ }^{9-13}$,

Address for correspondence: Prof. Dr Halise Inci Gul, Department of Pharmaceutical Chemistry, Faculty of Pharmacy, Ataturk University, 25240, Erzurum, Turkey. Tel: +90 442 2325203. Fax: +90 4422360962. E-mail: incigul1967@yahoo.com.

\section{Keywords}

Cytotoxicity, Huh7, hydrazone, Mannich bases, mitochondrial respiration, T47D

\section{History}

Received 5 March 2013

Revised 8 April 2013

Accepted 10 April 2013

Published online 15 July 2013 anti-cancer $^{8}$, anti-inflammatory ${ }^{14}$, anti-convulsant ${ }^{15}$ and antifungal $^{16,17}$ activities. Their cytotoxic activities may be attributed to the $\alpha, \beta$-unsaturated ketone, which is available in the chemical structure of the compound or is produced by deamination process in vivo or under simulated conditions in vitro ${ }^{18-20}$ or inhibition of mitochondrial respiration ${ }^{21,22}$.

In the $1920 \mathrm{~s}$, Warburg et al. ${ }^{23}$ showed that tumour cells produce large quantities of lactic acid from glucose via the glycolytic pathway, even under aerobic conditions. It has been proposed that this so-called "aerobic glycolysis" and the consequent export of lactic acid leads to the low extracellular $\mathrm{pH}(\mathrm{pHe})$ characteristic of solid tumours. More recent works suggest that other metabolic pathways may also contribute to acid production $^{24,25}$. Alternatively, the pHe of solid tumours may be independantly regulated in vivo because it is an intrinsic part of the tumour phenotype ${ }^{26}$. A theoretical model has proposed that a low pHe may confer survival and growth advantages for tumour cells at the expense of the surrounding normal cells ${ }^{27}$ and in vitro studies have shown that a low pHe favours metastatic behaviour and production of angiogenic factors by human cells ${ }^{28,29}$. In any case, as the intracellular $\mathrm{pH}$ (pHi) is tightly controlled and maintained at neutral or slightly alkaline levels, the low $\mathrm{pHe}$ of solid tumours leads to a $\mathrm{pH}$ gradient ( $\mathrm{pHe}-\mathrm{pHi}$ ) across the plasma membrane, which is the reverse of that found in normal tissue $\mathrm{e}^{30}$. This reverse or negative $\mathrm{pH}$ gradient $(\Delta \mathrm{pH})$ can also have important consequences for the effective delivery of chemotherapeutic drugs from the blood stream to the tumour intracellular space ${ }^{31}$. 
A large $-\Delta \mathrm{pH}$ has been shown to be an important determinant for tumour cell uptake of the anti-cancer drug 5-fluorouracil ${ }^{32,33}$, and a low pHe favours cellular uptake of other chemotherapeutic drugs that are weak acids, such as chlorambucil, or reduces uptake of weak bases such as mitoxanthrone $\mathrm{e}^{6,34,35}$.

The $\mathrm{pH}$ of tumours grown s.c. from 30 human tumour xenograft lines in rats were analysed with the use of $\mathrm{H}^{+}$ionsensitive semi-microelectrodes prior to and following stimulation of tumour cell glycolysis by intravenous infusion of glucose. Without exception, all xenografts responded to the temporary increase in plasma glucose concentration by an accumulation of acidic metabolites, as indicated by a $\mathrm{pH}$ reduction to an average value of 6.43 from 6.83 . This $\mathrm{pH}$ value corresponds to a ten-fold increase in $\mathrm{H}^{+}$ion activity in tumour tissues as compared to arterial blood ${ }^{36}$. If this is the case, tumour-selective activation of pH-sensitive anti-cancer agents, e.g. alkylating drugs, acid-labile prodrugs or $\mathrm{pH}$-sensitive immunoconjugates may thus be feasible in a wide variety of human cancers.

Hydrazones are a special group of compounds in the Schiff base family among condensation compounds which are synthesized with aldehyde or ketones and amine derivatives in organic chemistry. A great attention has been focused on hydrazones for many researchers because of their various biological activities such as anti-microbial, anti-fungal, anti-inflammatory anti-tubercular, anti-convulsant, anti-tumoural and anti-viral activities $^{37}$.

Some polymeric micellar drug delivery systems having hydrazone structure were developed for the delivery of doxorubi$\operatorname{cin}^{38}$. Hydrazone bond was included as it is cleavable under biologically relevant conditions under slightly acidic conditions ( $\mathrm{pH}$ ca. 5, typical of the interstitial space of most solid tumours and of the endosomal environment) and is relatively stable under neutral conditions in blood plasma $(\mathrm{pH} \mathrm{7.4})^{39,40}$. It was expected that this should minimize the release of toxic-free doxorubicin during delivery into tumour tissue and thus decrease side effects and increase the range of doses exploitable in therapy. In another study, the anti-cancer drug, adriamycin is conjugated to the coreforming segments through the hydrazone linkers that are stable under physiological conditions $(\mathrm{pH}$ 7.4), but cleavable under acidic intracellular environments in endosomes and lysosomes $(\mathrm{pH} 5-6)^{41}$.

Considering above mentioned problems and the logic explained, the design and synthesis of hydrazones of some Mannich bases, N,N'-bis[1-aryl-3-(piperidine-1-yl)propylidene]hydrazine dihydrochlorides, were considered to develop new anti-cancer drug candidates. These compounds were designed as bi-functional alkylating agents and prodrug of Mannich bases, which can provide $\alpha, \beta$-unsaturated ketones responsible for the cytotoxicity of them following hydrolysis of hydrazone in acidic environment of cancer cells to produce 2 mols of mono Mannich bases from $1 \mathrm{~mol}$ of hydrazone compound first. Then, they undergo deamination to produce $\alpha, \beta$-unsaturated ketones which alkylate thiols. Another approach can be deamination of hydrazone first and then reaction of the product generated with cellular thiols by alkylation to produce cytototoxicity.

In addition, as it was previously shown that cytotoxic Mannich bases derived from styryl ketones inhibit mitochondrial respiration in rat liver cells ${ }^{21,22}$. Inhibition of mitochondrial respiratory chain by the representative compound $\mathbf{P 7}$ was also tested in liver homogenate to elucidate the possible mechanisms of actions of the acid-sensitive hydrazones derived from mono Mannich bases.

\section{Experimental}

\section{Chemistry}

Melting points were determined on an Electrothermal 9100 melting point apparatus (IA9100, Electrothermal, Essex, UK). ${ }^{1} \mathrm{H}$ $(400 \mathrm{MHz})$ and ${ }^{13} \mathrm{C}(100 \mathrm{MHz})$ NMR spectra were recorded employing a Varian $400 \mathrm{MHz}$ FT spectrometer (Danbury, CT) for hydrazone derivatives P1-P8, while ${ }^{1} \mathrm{H}(60 \mathrm{MHz})-\mathrm{NMR}$ spectra were recorded on a Varian EM-360 spectrometer for precursor mono Mannich bases P1m-P8m. NMR spectra of P1-P8 were measured in $\mathrm{MeOH}-\mathrm{d}_{4}$ solutions using tetra methyl silane as an internal standard and chemical shifts are reported as parts per million $(\delta)$ while $\mathrm{CDCl}_{3}$ was used for $\mathbf{P 1 m}-\mathbf{P 8 m}$. Coupling constants $(J)$ are reported in Hertz. HRMS were recorded on a V6 Waters Micromass ZQ (Waters Corporation, Milford, MA) and UV spectra were taken on a Thermo Electron He $\lambda$ ios $(\alpha)$ (UVA 114903, Cambridge, UK) spectrophotometer for hydrazone derivatives. Synthetic starting material, reagents and solvents were purchased from Merck-Schuchardt (Hohenbrunn, Germany), Riedel-de Haën (Seelze, Germany), J.T. Baker Chemical Company (Phillipsburg, NJ), Fluka AG (Buchs, Switzerland), Acros Organics Chemical Co. (Fair Lawn, NJ) and Sigma-Aldrich Chemical Co. (St. Louis, MO).

General procedure for the synthesis of precursor mono Mannich bases, 1-aryl-3-(piperidine-1-yl)-1-propanone hydrochlorides, (P1m-P8m)

Except P2m, the mixture of corresponding acetophenone, paraformaldehyde and piperidine hydrochloride in 1:1.5:1 mol ratio was dissolved in ethanol. A few drops of $\mathrm{HCl}$ (37\%) was added into this mixture. Reaction content was refluxed for sometime. Solvent was removed under vacuum. The residue obtained was crystallized from suitable solvent. Crystals formed were filtered, washed with diethyl ether, dried and crystallized. The amount of suitable ketone ( $\mathrm{mmol}$ ), heating period (h), melting point $\left({ }^{\circ} \mathrm{C}\right)$, crystallization solvent and yield $(\%)$ of the compounds P1m-P8m (Scheme 1) were as follows: P1m (20 mmol, 9h, $191-194{ }^{\circ} \mathrm{C}$, methanol, 69\%), P2m (8 mmol, $22 \mathrm{~h}, 182-187^{\circ} \mathrm{C}$, methanol-ether, $25 \%$ ), P3m (30 mmol, $4 \mathrm{~h}$,

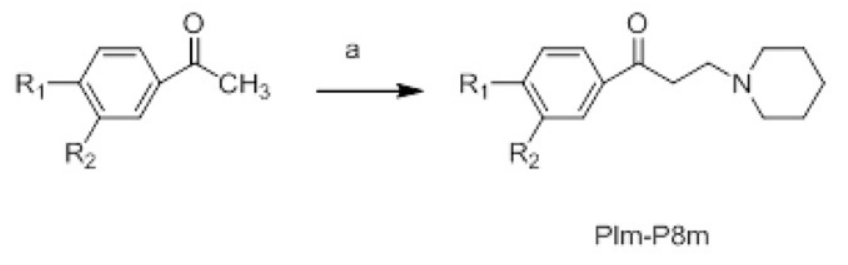

PIm-P8m

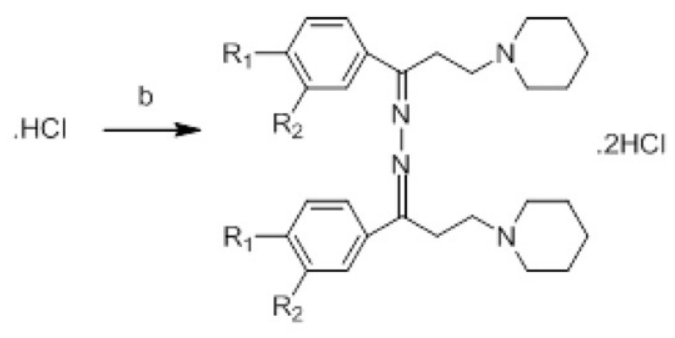

P1-P8

Scheme 1. Synthesis of N,N'-Bis[1-aryl-3-(piperidine-1-yl)propylidene]hydrazine dihydrochlorides, P1-P8. Reagents and conditions: (a) paraformaldehyde, piperidine $\mathrm{HCl}, \mathrm{HCl}$ (37\%) and $\mathrm{EtOH}, 4-9 \mathrm{~h}$, for $\mathbf{P 1 m}, \mathbf{P 3 m}-\mathbf{P 8 m}$; acetic acid (99\%), 22 h, for P2m; (b) Ethanolic acetic acid (3\% w/v), hydrazine hydrate for P1-P8. $\quad \mathrm{R}_{1}=\mathrm{R}_{2}=\mathrm{H}(\mathbf{P 1}) ; \mathrm{R}_{1}=\mathrm{CH}_{3}, \mathrm{R}_{2}=\mathrm{H}(\mathbf{P 2}) ; \mathrm{R}_{1}=\mathrm{CH}_{3} \mathrm{O}, \mathrm{R}_{2}=\mathrm{H}(\mathbf{P 3}) ; \mathrm{R}_{1}=\mathrm{OH}, \mathrm{R}_{2}=\mathrm{H}(\mathbf{P 4}) ; \mathrm{R}_{1}=\mathrm{Cl}, \mathrm{R}_{2}=\mathrm{H}$ (P5); $\mathrm{R}_{1}=\mathrm{H}, \mathrm{R}_{2}=\mathrm{CH}_{3} \mathrm{O}(\mathbf{P 6}) ; \mathrm{R}_{1}=\mathrm{F}, \mathrm{R}_{2}=\mathrm{H}(\mathbf{P} 7) ; \mathrm{R}_{1}=\mathrm{Br}, \mathrm{R}_{2}=\mathrm{H}(\mathbf{P 8})$. 
215-218 ${ }^{\circ} \mathrm{C}$, ethanol, 32\%), P4m (30 mmol, 4h, 224-226 ${ }^{\circ} \mathrm{C}$, ethanol, 33\%), P5m (20 mmol, $9 \mathrm{~h}, 196-198^{\circ} \mathrm{C}$, methanol-ether, 48\%), P6m (30 mmol, $8 \mathrm{~h}, 152-155^{\circ} \mathrm{C}$, ethanol-ether, $\left.45 \%\right)$, P7m (20 mmol, $8 \mathrm{~h}, 173-177^{\circ} \mathrm{C}$, methanol, $\left.21 \%\right)$, P8m $(20 \mathrm{mmol}, 8 \mathrm{~h}$, 205-207 ${ }^{\circ} \mathrm{C}$, methanol, $41 \%$ ). As precursor Mannich bases were registered in literatures with their melting points ${ }^{42-45}$, NMR data of them was not reported here. In the case of $\mathbf{P 2} \mathbf{m}$, the mol ratio of ketone, aldehyde and amine was 1:2:1. Acetic acid $(99 \%$, $30 \mathrm{ml}$ ) was used instead of ethanol. After refluxing $22 \mathrm{~h}$, the solvent was evoporated in vacuo and diethyl ether was added into the residue and the mixture was cooled for one night at $4{ }^{\circ} \mathrm{C}$. The precipitated compound was filtered, dried and crystallized from methanol-diethyl ether.

General procedure for the synthesis of hydrazones, N, N'-bis[1aryl-3-(piperidine-1-yl)propylidene]hydrazine dihydrochlorides (P1-P8)

A solution of hydrazine hydrate ( $1 \mathrm{~mol}$ ratio) in ethanol was added to a solution of mono Mannich base ( 2 mol ratio) in ethanolic acetic acid $(3 \% \mathrm{w} / \mathrm{v})$. The mixture was stirred at room temperature for $17-26 \mathrm{~h}$. The precipitated compound was filtered, dried and crystallized from suitable solvent to give the corresponding hydrazone derivatives. The crystals formed were filtered and dried at room temperature. Experimental data of $\mathbf{P}$-series hydrazone compounds, P1-P8 (Scheme 1) are shown in Table 1.

N,N'-bis[1-phenyl-3-(piperidine-1-yl)propylidene] hydrazine dihydrochlorides (P1). Yield: 57\%. M.p. $185-189^{\circ} \mathrm{C}$. UV $\lambda_{m a k s}^{\mathrm{MeOH}}$ $(\log \varepsilon) 303(4.22) \mathrm{nm} .{ }^{1} \mathrm{H}$ NMR $\left(\mathrm{MeOH}_{-}\right) \delta 1.80-1.95(\mathrm{~m}$, $12 \mathrm{H}), 2.97$ (m, 8H), 3.54-3.63 (m, 8H), 7.51-7.56 (m, 8H), 8.03$8.06(\mathrm{~m}, 2 \mathrm{H}) ;{ }^{13} \mathrm{C}$ NMR $\left(\mathrm{MeOH}_{-} \mathrm{d}_{4}\right) \delta 21.39,23.05,23.74,53.15$, $53.5,127.39,128.92,131.09,136.05,163.27$. HRMS: 431.32 $\left(\mathrm{M}^{+}\right), 432.32(\mathrm{M}+1)^{+}$.

N,N'-bis[1-(4-methylphenyl)-3-(piperidine-1-yl)propylidene] hydrazine dihydrochlorides $(\boldsymbol{P 2})$. Yield: 9\%. M.p. $207-210{ }^{\circ} \mathrm{C}$. $\mathrm{UV} \lambda_{\text {maks }}^{\mathrm{MeOH}}(\log \varepsilon) 313(4.28) \mathrm{nm} .{ }^{1} \mathrm{H}$ NMR $\left(\mathrm{MeOH}-\mathrm{d}_{4}\right) \delta 1.85(\mathrm{~m}$, $12 \mathrm{H}), 2.41(\mathrm{~s}, 6 \mathrm{H}), 2.99(\mathrm{~m}, 8 \mathrm{H}), 3.52-3.63(\mathrm{~m}, 8 \mathrm{H}), 7.35(\mathrm{~d}$, $J=7.7 \mathrm{~Hz}, 4 \mathrm{H}), 7.94(\mathrm{t}, J=8.4 \mathrm{~Hz}, 4 \mathrm{H}) ;{ }^{13} \mathrm{C} \mathrm{NMR}\left(\mathrm{MeOH}-\mathrm{d}_{4}\right) \delta$ 20.23, 21.41, 23.05, 23.61, 53.14, 53.67, 127.36, 129.53, 133.33, 141.77, 163.08. HRMS 459.35 $\left(\mathrm{M}^{+}\right), 460.35(\mathrm{M}+1)^{+}$.

$N, N^{\prime}$-bis[1-(4-methoxyphenyl)-3-(piperidine-1-yl)propylidene] hydrazine dihydrochlorides (P3). Yield: 72\%. M.p. $214-217^{\circ} \mathrm{C}$. $\mathrm{UV} \lambda_{\text {maks }}^{\mathrm{MeOH}}(\log \varepsilon) 276(4.38) \mathrm{nm} .{ }^{1} \mathrm{H}$ NMR $\left(\mathrm{MeOH}-\mathrm{d}_{4}\right) \delta 1.85-$ $1.92(\mathrm{~m}, 12 \mathrm{H}), 3.30(\mathrm{~m}, 8 \mathrm{H}), 3.49-3.58(\mathrm{~m}, 8 \mathrm{H}), 3.88(\mathrm{~s}, 6 \mathrm{H})$, $7.04(\mathrm{~d}, J=9.2 \mathrm{~Hz}, 4 \mathrm{H}), 8.03(\mathrm{~d}, J=8.8 \mathrm{~Hz}, 4 \mathrm{H}) ;{ }^{13} \mathrm{C} \mathrm{NMR}$ $\left(\mathrm{MeOH}_{-} \mathrm{d}_{4}\right) \delta 21.43,23.04,32.38,52.41,53.59,54.95,113.86$, 129.02, 130.51, 164.62, 195.17. HRMS $491.34\left(\mathrm{M}^{+}\right), 492.34$ $(\mathrm{M}+1)^{+}$.
$N, N^{\prime}$-bis [1-(4-hydroxyphenyl)-3-(piperidine-1-yl)propylidene] hydrazine dihydrochlorides (P4). Yield: 64\%. M.p. 219-221 ${ }^{\circ} \mathrm{C}$. $\mathrm{UV} \lambda_{\text {maks }}^{\mathrm{MeOH}}(\log \varepsilon) 281(4.36) \mathrm{nm} .{ }^{1} \mathrm{H}$ NMR $\left(\mathrm{MeOH}-\mathrm{d}_{4}\right) \delta 1.89(\mathrm{~m}$, $12 \mathrm{H}), 3.30(\mathrm{~m}, 8 \mathrm{H}), 3.50-3.53(\mathrm{~m}, 8 \mathrm{H}), 6.87(\mathrm{~d}, J=8.8 \mathrm{~Hz}, 4 \mathrm{H})$, $7.94(\mathrm{~d}, J=8.8 \mathrm{~Hz}) ;{ }^{13} \mathrm{C} \mathrm{NMR}\left(\mathrm{MeOH}-\mathrm{d}_{4}\right) \delta 21.43,23.04,32.21$, $52.48,53.57,115.22,127.92,130.75,163.20,195.07$. HRMS $463.30\left(\mathrm{M}^{+}\right)$.

$N, N^{\prime}$-bis [1-(4-chlorophenyl)-3-(piperidine-1-yl)propylidene] hydrazine dihydrochlorides (P5). Yield: $48 \%$. M.p. $184-189^{\circ} \mathrm{C}$. $\mathrm{UV} \lambda_{\text {maks }}^{\mathrm{MeOH}}(\log \varepsilon) 254$ (4.32), 311 (4.06) nm. ${ }^{1} \mathrm{H}$ NMR (MeOH$\left.\mathrm{d}_{4}\right) \delta 1.57-1.93(\mathrm{~m}, 12 \mathrm{H}), 3.04-3.15(\mathrm{~m}, 8 \mathrm{H}), 3.51-3.63(\mathrm{~m}, 8 \mathrm{H})$, $7.55(\mathrm{~d}, J=7.7 \mathrm{~Hz}, 4 \mathrm{H}), 8.04(\mathrm{~d}, J=8.8 \mathrm{~Hz}, 4 \mathrm{H}) ;{ }^{13} \mathrm{C} \mathrm{NMR}$ $\left(\mathrm{MeOH}-\mathrm{d}_{4}\right) \delta 21.41,23.06,32.93,52.15,53.64,128.96,129.78$, 134.7, 139.99, 195.5. HRMS 499.24 $\left(\mathrm{M}^{+}\right), 501.24(\mathrm{M}+2)^{+}$.

$N, N^{\prime}$-bis [1-(3-methoxyphenyl)-3-(piperidine-1-yl)propylidene] hydrazine dihydrochlorides (P6). Yield: 88\%. M.p. $187-192^{\circ} \mathrm{C}$. $\mathrm{UV} \lambda_{\text {maks }}^{\mathrm{MeOH}}(\log \varepsilon) 251$ (3.94), 308 (3.67) nm. ${ }^{1} \mathrm{H}$ NMR (MeOH$\left.\mathrm{d}_{4}\right) \delta 1.84(\mathrm{~m}, 12 \mathrm{H}), 3.26(\mathrm{~m}, 8 \mathrm{H}), 3.53-3.59(\mathrm{~m}, 8 \mathrm{H}), 3.88(\mathrm{~s}$, $6 \mathrm{H}), 7.13(\mathrm{dd}, J=8.3,2.6 \mathrm{~Hz}, 2 \mathrm{H}), 7.46(\mathrm{t}, J=8.1 \mathrm{~Hz}, 2 \mathrm{H}), 7.55$ $(\mathrm{t}, J=2.2 \mathrm{~Hz}, 2 \mathrm{H}), 7.58(\mathrm{td}, J=7.7,2.6 \mathrm{~Hz}) ;{ }^{13} \mathrm{C} \mathrm{NMR}(\mathrm{MeOH}-$ $\left.\mathrm{d}_{4}\right) \delta 21.4,23.03,23.91,53.19,53.55,54.96,113.01,116.38$, $119.83,130.1,137.4,160.44,163.01$; HRMS $491.34\left(\mathrm{M}^{+}\right)$, $492.34(\mathrm{M}+1)^{+}$.

$N, N^{\prime}$-bis [1-(4-fluorophenyl)-3-(piperidine-1-yl)propylidene] hydrazine dihydrochlorides (P7). Yield: $12 \%$. M.p. 204-209 ${ }^{\circ} \mathrm{C}$. $\mathrm{UV} \lambda_{\text {maks }}^{\mathrm{MeOH}}(\log \varepsilon) 306(4.30) \mathrm{nm} .{ }^{1} \mathrm{H}$ NMR $\left(\mathrm{MeOH}-\mathrm{d}_{4}\right) \delta 1.80$ $1.86(\mathrm{~m}, 12 \mathrm{H}), 2.99(\mathrm{~m}, 8 \mathrm{H}), 3.52-3.60(\mathrm{~m}, 8 \mathrm{H}), 7.27(\mathrm{t}$, $J=8.8 \mathrm{~Hz}, 4 \mathrm{H}), 8.11(\mathrm{~d}, J=8.8 \mathrm{~Hz}, 4 \mathrm{H}) ;{ }^{13} \mathrm{C} \mathrm{NMR}\left(\mathrm{MeOH}-\mathrm{d}_{4}\right) \delta$ 21.42, 23.05, 23.72, 53.18, 53.4, 115.91, 129.9, 132.37, 163.61, 166.11. HRMS $467.3\left(\mathrm{M}^{+}\right), 468.3(\mathrm{M}+1)^{+}$.

N, $N^{\prime}$-bis [1-(4-bromophenyl)-3-(piperidine-1-yl)propylidene] hydrazine dihydrochlorides (P8). Yield: $14 \%$. M.p. $195-199^{\circ} \mathrm{C}$. UV $\lambda_{\text {maks }}^{\mathrm{MeOH}}(\log \varepsilon) 263$ (4.13), 313 (4.30) nm. ${ }^{1} \mathrm{H}$ NMR (MeOH$\left.\mathrm{d}_{4}\right) \delta 1.84-2.01(\mathrm{~m}, 12 \mathrm{H}), 3.03(\mathrm{~m}, 8 \mathrm{H}), 3.50-3.61(\mathrm{~m}, 8 \mathrm{H}), 7.72$ $(\mathrm{d}, J=8.8 \mathrm{~Hz}, 4 \mathrm{H}), 7.96(\mathrm{~d}, J=8.8 \mathrm{~Hz}, 4 \mathrm{H}) ;{ }^{13} \mathrm{C} \mathrm{NMR}(\mathrm{MeOH}-$ $\left.\mathrm{d}_{4}\right) \delta 21.39,23.04,32.84,52.12,53.66,128.67,129.82,132.03$, 135.04, 195.71. HRMS 587.14 $\left(\mathrm{M}^{+}\right), 589.14(\mathrm{M}+2)^{+}, 591.14$ $(\mathrm{M}+4)^{+}$.

\section{Cytotoxic activity assay}

Hydrazone compounds, P1-P8 and 5-FU, which was used as positive control compound, were tested against human hepatoma (Huh7) and breast cancer (T47D) cells by NCI-60 SulforhodamineB Assay ${ }^{46,47}$ to identify the compounds with growth-inhibitory activity. Briefly, T47D and Huh7 cells (5000 or 10000 ) were inoculated into 96-well plates in $100 \mu \mathrm{l}$ of standard DMEM medium (Gibco-Invitrogen Corp., Grand Island, NY) 24 h

Table 1. Experimental data of $\mathbf{P}$ series hydrazone compounds, P1-P8 (Scheme 1).

\begin{tabular}{llccccc}
\hline Compound & \multicolumn{1}{c}{ Formula } & MW & Reaction time $(\mathrm{h})$ & Crystallization solvent & Yield (\%) & Melting point $\left({ }^{\circ} \mathrm{C}\right)$ \\
\hline P1 & $\mathrm{C}_{28} \mathrm{H}_{40} \mathrm{Cl}_{2} \mathrm{~N}_{4}$ & 502.26 & 17 & Ethanol & 57 & $185-189^{*}$ \\
P2 & $\mathrm{C}_{30} \mathrm{H}_{44} \mathrm{Cl}_{2} \mathrm{~N}_{4}$ & 530.29 & 23 & Ethanol & 9 & $208-210$ \\
P3 & $\mathrm{C}_{30} \mathrm{H}_{44} \mathrm{Cl}_{2} \mathrm{~N}_{4} \mathrm{O}_{2}$ & 562.28 & 18 & Methanol & 72 & $214-217$ \\
P4 & $\mathrm{C}_{28} \mathrm{H}_{40} \mathrm{Cl}_{2} \mathrm{~N}_{4} \mathrm{O}_{2}$ & 534.25 & 18 & Ethanol & 64 & $219-221$ \\
P5 & $\mathrm{C}_{28} \mathrm{H}_{38} \mathrm{Cl}_{4} \mathrm{~N}_{4}$ & 570.19 & 18 & Ethanol & 48 & $186-189$ \\
P6 & $\mathrm{C}_{30} \mathrm{H}_{44} \mathrm{Cl}_{2} \mathrm{~N}_{4} \mathrm{O}_{2}$ & 562.28 & 26 & Chloroform & 88 & $190-192$ \\
P7 & $\mathrm{C}_{28} \mathrm{H}_{38} \mathrm{Cl}_{2} \mathrm{~F}_{2} \mathrm{~N}_{4}$ & 538.24 & 26 & Chloroform/methanol & 12 & $204-209$ \\
P8 & $\mathrm{C}_{28} \mathrm{H}_{38} \mathrm{Br}_{2} \mathrm{Cl}_{2} \mathrm{~N}_{4}$ & 658.08 & 20 & Ethyl acetate/methanol & 14 & $195-199$ \\
\hline
\end{tabular}

*Reported melting point of $\mathbf{P 1}$ was $172.5-175^{\circ} \mathrm{C}^{52}$. 
prior to treatment with the compounds in increasing concentrations $(2.5,5,10,20,40 \mu \mathrm{M})$. After $72 \mathrm{~h}$ of treatment, the cell culture medium was discarded and the cells were washed with $1 \times$ PBS $\left(\mathrm{CaCl}_{2^{-}}, \mathrm{MgCl}_{2}\right.$-free) (Gibco, Invitrogen). Then cells were fixed by gentle addition of $50 \mu \mathrm{l}$ of ice-cold $10 \%$ (w/v) trichloroacetic acid (MERCK) for $60 \mathrm{~min}$ at $4{ }^{\circ} \mathrm{C}$. After fixation, cells were washed with distilled water and dried in air. The cells were stained using $50 \mu \mathrm{l}$ of a $0.4 \%(\mathrm{~m} / \mathrm{v})$ of sulforhodamine (SigmaAldrich) in $1 \%$ acetic acid solution at room temperature for $10 \mathrm{~min}$. Extra unbound dye was washed five times with $200 \mu \mathrm{l}$ of $1 \%$ acetic acid and air-dried. Sulforhodamine stain, which was bound to cellular proteins, was then solubilized by adding $200 \mu \mathrm{l}$ of $10 \mathrm{mM}$ Tris-base solution and the absorbance was acquired at $515 \mathrm{~nm}$. Absorbance values of the compounds were normalized to their corresponding controls (DMSO). The $\mathrm{IC}_{50}$ values were calculated as previously described ${ }^{48}$. The $\mathrm{IC}_{50}$ values reported are the average of two independent determinations which differed by $<10 \%$.

\section{Inhibition of mitochondrial respiration assay}

\section{Animals}

Experiments were performed on nine adult male Wistar rats (8week-old), housed in a thermo-neutral environment $\left(22 \pm 2{ }^{\circ} \mathrm{C}\right)$, on a $12: 12 \mathrm{~h}$ photoperiod, and provided food and water ad libitum. This investigation was carried out in accordance with the Guide for the Care and Use of Laboratory published by the US National Institute of Health and approved by the institutional animal care commitee (NIH publication No. 85-23, revised 1996). Animals were submitted to a general anaesthesia with isoflurane and the liver was excised and immediately used for the study of mitochondrial respiration.

\section{Study of mitochondrial respiration}

Isolation of liver mitochondria. All operations were carried out at $4{ }^{\circ} \mathrm{C}$. Liver was finely minced in ice-cold isolation buffer $(50 \mathrm{mM}$ Tris, $1 \mathrm{mM}$ EGTA, $70 \mathrm{mM}$ Sucrose, $210 \mathrm{mM}$ Mannitol, pH 7.4 at $4{ }^{\circ} \mathrm{C}$ ) and then homogenized with a Potter-Elvehjem device. The homogenate was centrifuged at $1300 \mathrm{~g}$ for $3 \mathrm{~min}$ at $4{ }^{\circ} \mathrm{C}$. The supernatant was centrifuged at $10000 \mathrm{~g}$ for $10 \mathrm{~min}$ at $4{ }^{\circ} \mathrm{C}$ to sediment mitochondria. Finally, the mitochondrial pellet was washed twice and then suspended in $50 \mathrm{mM}$ Tris, $70 \mathrm{mM}$ Sucrose, $210 \mathrm{mM}$ Mannitol, pH 7.4 at $4{ }^{\circ} \mathrm{C}$. Protein content was routinely assayed with a Bradford assay using bovine serum albumin (BSA) as a standard ${ }^{49}$. Mitochondria were kept on ice until use.

Measurement of the mitochondrial respiratory chain complexes. Mitochondrial respiration was measured using a Clark-type electrode (Strathkelvin Instruments, Glasgow, UK) as previously reported ${ }^{50}$. Before oxygraph measurement, $3 \mathrm{ml}$ of solution M (100 mM KCl, 50 mM Mops, 1 mM EGTA, 5 mM Kpi, $1 \mathrm{mg} / \mathrm{ml} \mathrm{BSA}$ ) was added to the oxygraph chambers for $10 \mathrm{~min}$ then, $0.15 \mathrm{mg}$ of isolated liver mitochondria were introduced with $10 \mathrm{mM}$ glutamate and $2.5 \mathrm{mM}$ malate and the temperature was maintained at $25^{\circ} \mathrm{C}$. After that, succinate $(25 \mathrm{mM})$ and adenosine diphosphate were added. Mitochondrial respiration in these conditions allowed determining the activities of the complexes I, II, III and IV (Figure 2). After that, the representative Fluor-bearing compound P7 was added at different concentrations.

Results are expressed as mean \pm SEM. Statistical analyses were performed using one-way ANOVA followed by a Newman-Keuls post-test. (GraphPad Prism 5, Graph Pad Software, Inc., San Diego, CA). Statistical significance required a $p<0.05$.

\section{Results}

In this study, hydrazone compounds $\mathbf{P 1 - P 8}$ bearing a piperidine moiety were synthesized as presented in Scheme 1 for the first time, except compound P1. Experimental data of P-series of compounds are presented in Table 1 . Compounds were obtained with the yield of 9-88\%. The chemical structures of newly synthesized compounds were assigned on the basis of their spectroscopic data such as UV, ${ }^{1} \mathrm{H}$ NMR and ${ }^{13} \mathrm{C}$ NMR and HRMS. Spectral data are presented at the experimental section. Spectral data of the compounds were in accordance with the chemical structures of the compounds synthesized.

All the synthesized compounds having the chemical structure of N,N'-bis[1-aryl-3-(piperidine-1-yl)propylidene]hydrazine dihydrochlorides were evaluated against the human hepatoma cells (Huh7) and breast cancer cells (T47D) in terms of cytotoxic activity. The cytotoxicity of the compounds and reference compound 5-FU are listed in Table 2 in terms of the inhibitory potencies $\left(\mathrm{IC}_{50}, \mu \mathrm{M}\right)$.

Hydrazone compounds, P1 (4.86 times), P2 (10.08 times), P7 (5.26 times) and P8 (1.07 times, almost equal to 5-FU) had higher cytotoxic potency than the reference compound, 5-FU, against Huh7 cells. Of the compounds synthesized, only P2, a 4-methyl derivative, had more potent cytotoxic activity than 5-FU against T47D cells (1.45 times). The representative cytotoxic compound P7 inhibited the mitochondrial respiration significantly at 144, 264 and $424 \mu \mathrm{M}$ concentrations dose-dependantly in liver homogenates (Figure 1).

Table 2. Cytotoxic activity of hydrazones P1-P8 (Scheme 1), against Huh7 and T47D cells $\left(\mathrm{IC}_{50}, \mu \mathrm{M}\right)$.

\begin{tabular}{lcc}
\hline Compound & Huh7 & T47D \\
\hline P1 & 8.66 & 19.90 \\
P2 & 4.18 & 4.83 \\
P3 & $*$ & $*$ \\
P4 & $*$ & 51.59 \\
P5 & $*$ & 114.93 \\
P6 & $*$ & 229.82 \\
P7 & 8.01 & 10.05 \\
P8 & 39.50 & 16.09 \\
5-FU & 42.12 & 7.0 \\
\hline
\end{tabular}

5-FU, 5-Fluorouracil; *, no inhibition.

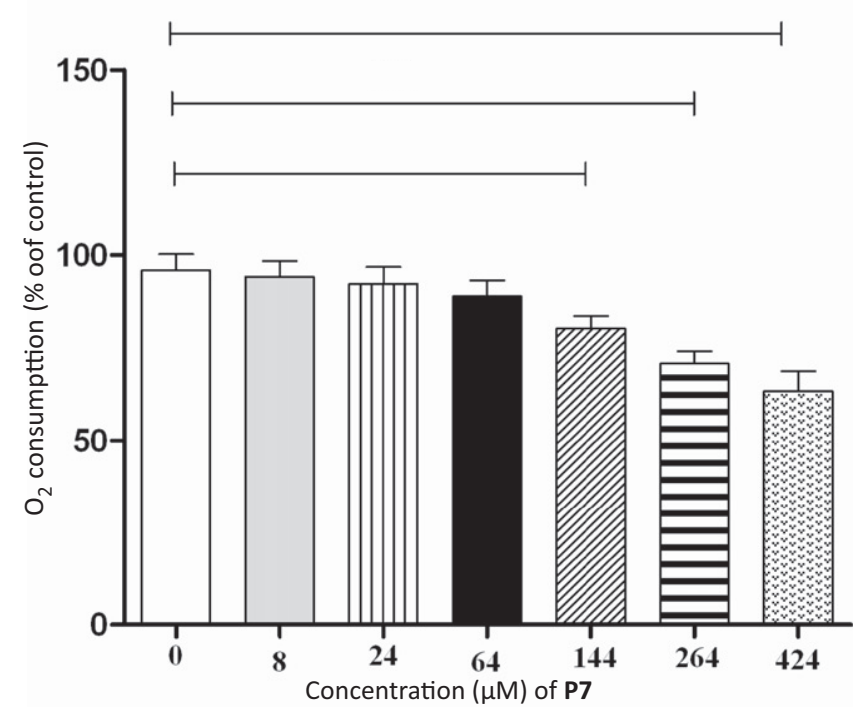

Figure 1. In vitro effects of increasing concentrations of $\mathbf{P 7}$ on rat liver mitochondrial respiratory chain. $p<0.05$ (one-way ANOVA followed by Tukey). 
Intermembrane space

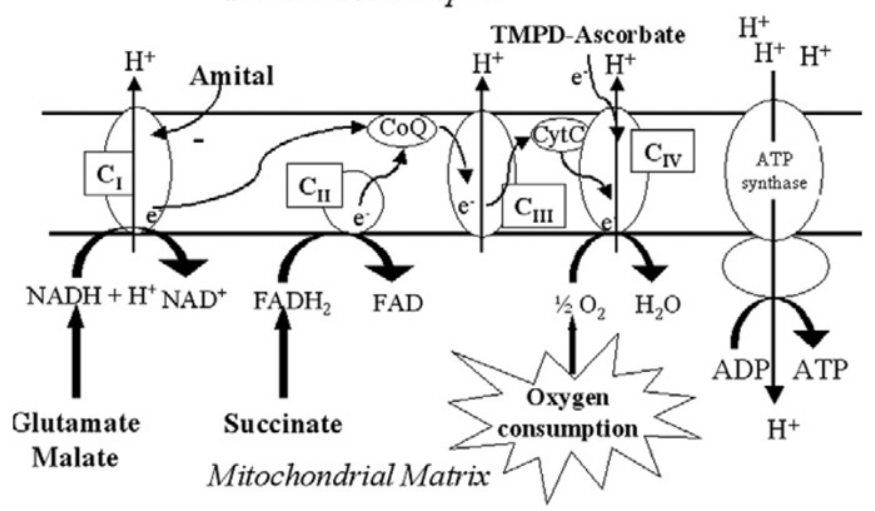

Figure 2. Schematic representation of the mitochondrial respiratory chain with specific substrates and inhibitors (modified from a previous study $^{53}$ ). CI, complex I; CII, complex II; CIII, complex III; CIV, complex IV; TMPD, N,N, $\mathrm{N}^{\prime}, \mathrm{N}^{\prime}$-tetramethyl-p-phenylenediamine dihydrochloride; $\mathrm{H}$, proton.

\section{Discussion}

In this study, hydrazone compounds were designed as acidsensitive compounds targeting cancer cells that have lower $\mathrm{pH}$ value than corresponding normal tissues. There are three suggested mechanisms of action for the cytotoxicity of designed chemical structures ${ }^{51,52}$ : firstly, hydrazone compounds may undergo deamination to produce N,N'-bis(1-arylpropylidene)hydrazine, then interact with cellular thiol to form cytotoxicity. Secondly, hydrazone compound undergoes hydrolysis at the acidic $\mathrm{pH}$ of cancer cells to produce 2 mols of mono Mannich bases (Pm-Series) from $1 \mathrm{~mol}$ of hydrazone (P-Series) first, then they may undergo deamination to produce biologically active species $\alpha, \beta$-unsaturated ketones, which alkylate cellular thiols to produce cytotoxicity. Thirdly, inhibition of mitochondrial respiration by the compounds.

The chemical structures of newly synthesized compounds were assigned on the basis of their spectroscopic data such as UV, ${ }^{1} \mathrm{H}$ NMR and ${ }^{13} \mathrm{C}$ NMR and HRMS. Spectral data are presented in the experimental section. Spectral data of the compounds were in accordance with the chemical structures of the compounds synthesized. As an example, compound P1's spectral data can be summarized. When examined, the ${ }^{1} \mathrm{H}$ NMR spectrum of P1, the protons on the phenyl ring in the molecule were observed as 2hydrogen-multiplet and 8-hydrogen-multiplet in $\delta 8.03-8.06 \mathrm{ppm}$ and $\delta 7.51-7.56 \mathrm{ppm}$, respectively. The protons belonged to ethylene chain between nitrogen atom of piperidine ring and carbon atom of imine group gave 8-hydrogen multiplet in $\delta$ $3.54-3.63 \mathrm{ppm}$. The protons of methylene group next to the nitrogen atom in piperidine ring were observed in $\delta 2.97 \mathrm{ppm}$ as 8-hydrogen multiplet. The other protons of piperidine ring gave 12-hydrogen multiplet in $\delta 1.80-1.95 \mathrm{ppm}$. In ${ }^{13} \mathrm{C} \mathrm{NMR}$ spectrum, the carbon signal belonged to the imine group, which has shown that expected structure had synthesized, was observed in $\delta 163.27 \mathrm{ppm}$ and it was the most important signal of the spectrum. The signal observed in $\delta 136.05 \mathrm{ppm}$ belonged to carbons of phenyl ring next to the imine group. The signals of other protons of phenyl ring was in $\delta 131.09 \mathrm{ppm}, \delta 128.92 \mathrm{ppm}$ and $\delta 127.39 \mathrm{ppm}$. The carbon atoms of methylene group next to nitrogen atom in piperidine ring gave signals of $\delta 53.50 \mathrm{ppm}$. The carbon atoms of ethylene chain next to nitrogen atom of piperidine ring was observed at $\delta 53.15 \mathrm{ppm}$, while the signal of carbon atoms in the same ring next to the imine group was in $\delta 23.74 \mathrm{ppm}$. The carbon atoms on the position 4 according to the nitrogen atom of piperidine ring gave signal in $\delta 23.05 \mathrm{ppm}$. In the spectrum, the signal observed in $\delta 21.39 \mathrm{ppm}$ belonged to the carbon atoms which were on positions 3 and 5 according to the nitrogen atom of piperidine ring. In HRMS spectrum of compound P1, molecular ion signal which confirmed the structure of $\mathbf{P 1}$ was observed in $\mathrm{m} / \mathrm{z}$ 431.32. $\mathbf{M}+1$ signal was in $\mathrm{m} / \mathrm{z}$ 432.32. The signal that had the highest rate of relative abundance and confirmed that the fragmentation of the molecule occured between the imine groups was in $\mathrm{m} / \mathrm{z}$ 216.16. In UV spectrum of compound P1, the signal which was observed in $303 \mathrm{~nm}$ belonged to the chromophor imine group-conjugated phenyl ring. This signal was due to $\pi \rightarrow \pi^{*}$ electronic transition of imine group.

When the relationships between the cytotoxicity of the compounds and physicochemical parameters tested (Hammett $\sigma$, Hansch $\pi$ and $\log$ P, data not shown) were investigated, there were no correlation. Data were analysed by using the bivariate, Pearson correlation method in SPSS for Windows program (IBM, New York, NY). Observed cytotoxicities with P-Series of compounds against cell lines used, may be explained with the optimum deamination ratio of the compounds in cancer cells tested to produce biologically active alkylation centre or interaction with some steps at the electron transport chain in mitochondria. On the other hand, absence of cytotoxicity with some compounds of $\mathbf{P}$ Series may be explained by faster deamination of the compounds than the optimal level in the tested cells, which can cause faster elimination of the active metabolite before reaching their target. Second explanation for the absence of cytotoxicity may be the lack of interaction with the proper receptors for the bioactivity or the production of 1-aryl-3-(3-aryl-4,5-dihydropyrazol-1-yl)propan-1-one, which does not have suitable centre for thiol alkylation. Third, the compounds which dont have cytotoxicity may not have any interaction with electron transport chain in mitochondria.

Previously, it was shown that cytotoxic Mannich bases derived from styryl ketones inhibit mitochondrial respiration in rat liver cells $^{21,22}$. Accordingly, inhibition of mitochondrial respiratory chain by the compound $\mathbf{P 7}$ in this study suggests that inhibition of mitochondrial respiration may be one of the contributing mechanisms to the cytotoxic activity of $\mathbf{P 7}$ and the other cytotoxic compounds.

\section{Conclusions}

In conclusion, new hydrazones synthesized having a piperidine moiety as potential anti-cancer candidate deserved further structural modification and pharmacological evaluation. We reported here the compounds $\mathbf{P 2}-\mathbf{P 8}$ for the first time with their synthesis, spectral analysis and cytotoxicities of the $\mathbf{P}$-series of compounds against Huh7 and T47D cell lines. Compounds P1 (4.86 times), P2 (10.08 times), P7 (5.26 times) and P8 (1.07 times, almost equal to 5-FU), against Huh7 cell line, compound P2 (1.45 times) against T47D cell line may serve as model candidate compounds for further synthetic designs and studies. Inhibition of the mitochondrial respiration by the representative compound P7 suggests that it may be one of the contributing mechanisms to the cytotoxic activity of the hydrozones.

\section{Acknowledgements}

Cytotoxicity experiments were performed at the KANILTEK anticancer biomolecule screening facility, Bilkent University.

\section{Declaration of interest}

The authors report no conflict of interest.

This study was supported by the Research Foundation of Ataturk University (Project Numbers: 2007/58 and 2011/54), Erzurum, Turkey. 


\section{References}

1. Bosch FX, Ribes J, Diaz M, Cleries R. Primary liver cancer: worldwide incidence and trends. Gastroenterology 2004;127:S5-16.

2. El-Serag HB, Rudolph KL. Hepatocellular carcinoma: epidemiology and molecular carcinogenesis. Gastroenterology 2007;132: 2557-76.

3. Bruix J, Sherman M. Management of hepatocellular carcinoma. Hepatology 2005;42:1208-36.

4. Bruix J, Sherman M. Management of hepatocellular carcinoma: an update. Hepatology 2011;53:1020-2.

5. Schwartz M, Roayaie S, Konstadoulakis M. Strategies for the management of hepatocellular carcinoma. Nat Clin Pract Oncol 2007;4:424-32.

6. Parkin DM, Bray F, Ferlay J, Pisani P. Global cancer statistics, 2002. CA Cancer J Clin 2005;55:74-108.

7. Bange J, Zwick E, Ullrich A. Molecular targets for breast cancer therapy and prevention. Nat Med 2001;7:548-52.

8. Dimmock JR, Kumar P. Anticancer and cytotoxic properties of Mannich bases. Curr Med Chem 1997;4:1-22.

9. Bilginer S, Gul HI, Mete E, et al. 1-(3-Aminomethyl-4-hydroxyphenyl)-3-pyridinyl-2-propen-1-ones: a novel group of tumourselective cytotoxins. J Enzyme Inhib Med Chem 2012, doi: 10.3109/ 14756366.2012.700927.

10. Gul HI, Das U, Pandit B, Li PK. Evaluation of the cytotoxicity of some mono-Mannich bases and their corresponding azine derivatives against androgen-independent prostate cancer cells. Arzneimittel-Forsch 2006;56:850-5.

11. Gul HI, Gul M, Erciyas E. Toxicity of some bis Mannich bases and corresponding piperidinols in the brine shrimp (Artemia salina) bioassay. J Appl Toxicol 2003;23:53-7.

12. Gul HI, Yerdelen KO, Gul M, et al. Synthesis of 4'-hydroxy-3'piperidinomethylchalcone derivatives and their cytotoxicity against PC-3 cell lines. Arch Pharm 2007;340:195-201.

13. Gul M, Mete E, Atalay $\mathrm{M}$, et al. Cytotoxicity of 1-Aryl-3buthylamino-1-propanone hydrochlorides against Jurkat and L6 cells. Arzneimittel-Forsch 2009;59:364-9.

14. Gul HI, Suleyman H, Gul M. Evaluation of the anti-inflammatory activity of N, $\mathrm{N}^{\prime}$-bis(3-dimethylamino-1-phenyl-propylidene) hydrazine dihydrochloride. Pharm Biol 2009;47:968-72.

15. Gul HI, Calis U, Ozturk Z, et al. Evaluation of anticonvulsant activities of bis(3-aryl-3-oxo-propyl)ethylamine hydrochlorides and 4-aryl-3-arylcarbonyl-1-ethyl-4-piperidinol hydrochlorides. Arzneimittel-Forsch 2007;57:133-6.

16. Gul HI, Sahin F, Gul M, et al. Evaluation of antimicrobial activities of several Mannich bases and their derivatives. Arch Pharm 2005; 338:335-8.

17. Mete E, Ozelgul C, Kazaz C, et al. Synthesis and antifungal activity of 1-aryl-3-phenethylamino-1-propanone hydrochlorides and 3aroyl-4-aryl-1-phenethyl-4-piperidinols. Arch Pharm 2010;343: 291-300.

18. Gul M, Atalay M, Gul HI, et al. The effects of some Mannich bases on heat shock proteins HSC70 and GRP75, and thioredoxin and glutaredoxin levels in Jurkat cells. Toxicol In Vitro 2005;19:573-80.

19. Gul M, Gul HI, Hanninen O. Effects of Mannich bases on cellular glutathione and related enzymes of Jurkat cells in culture conditions. Toxicol In Vitro 2002;16:107-12.

20. Gul M, Gul HI, Vepsalainen J, et al. Effect of acetophenone derived Mannich bases on cellular glutathione level in jurkat cells - A possible mechanism of action. Arzneimittel-Forsch 2001;51:679-82.

21. Dimmock JR, Shyam K, Hamon NW, et al. bis-Mannich bases of styryl ketones as antileukemic agents. Neoplasma 1985;32:85-91.

22. Hamon NW, Bassendowski DL, Wright DE, et al. Effect of antineoplastic and cytotoxic Mannich Bases derived from conjugated styryl ketones on mitochondrial respiration in rat liver cells. J Pharm Sci 1978;67:1539-42.

23. Warburg O, Wind F, Neglers E. On the metabolism of tumours in the body. In: Warburg O, ed. Metabolism of tumors. London: Arnold Constable; 1930:254-70.

24. Newell K, Franchi A, Pouyssegur J, Tannock I. Studies with glycolysis-deficient cells suggest that production of lactic acid is not the only cause of tumor acidity. Proc Natl Acad Sci USA 1993;90: 1127-31.

25. Yamagata M, Hasuda K, Stamato T, Tannock IF. The contribution of lactic acid to acidification of tumours: studies of variant cells lacking lactate dehydrogenase. Br J Cancer 1998;77:1726-31.
26. Stubbs M, McSheehy PM, Griffiths JR. Causes and consequences of acidic $\mathrm{pH}$ in tumors: a magnetic resonance study. Adv Enzyme Regul 1999;39:13-30.

27. Gatenby RA. The potential role of transformation-induced metabolic changes in tumor-host interaction. Cancer Res 1995;55: 4151-6.

28. Griffiths L, Dachs GU, Bicknell R, et al. The influence of oxygen tension and $\mathrm{pH}$ on the expression of platelet-derived endothelial cell growth factor/thymidine phosphorylase in human breast tumor cells grown in vitro and in vivo. Cancer Res 1997; 57:570-2.

29. Martinez-Zaguilan R, Seftor EA, Seftor RE, et al. Acidic pH enhances the invasive behavior of human melanoma cells. Clin Exp Metastasis 1996;14:176-86.

30. Stubbs M, Rodrigues L, Howe FA, et al. Metabolic consequences of a reversed $\mathrm{pH}$ gradient in rat tumors. Cancer Res 1994;54: 4011-16.

31. Gerweck LE, Seetharaman K. Cellular pH gradient in tumor versus normal tissue: potential exploitation for the treatment of cancer. Cancer Res 1996;56:1194-8.

32. McSheehy PM, Seymour MT, Ojugo AS, et al. A pharmacokinetic and pharmacodynamic study in vivo of human HT29 tumours using 19F and 31P magnetic resonance spectroscopy. Eur J Cancer 1997; 33:2418-27.

33. Ojugo AS, McSheehy PM, Stubbs M, et al. Influence of $\mathrm{pH}$ on the uptake of 5-fluorouracil into isolated tumour cells. Br J Cancer 1998;77:873-9.

34. Vukovic V, Tannock IF. Influence of low $\mathrm{pH}$ on cytotoxicity of paclitaxel, mitoxantrone and topotecan. Br J Cancer 1997;75: 1167-72.

35. Kozin SV, Gerweck LE. Cytotoxicity of weak electrolytes after the adaptation of cells to low $\mathrm{pH}$ : role of the transmembrane $\mathrm{pH}$ gradient. Br J Cancer 1998;77:1580-5.

36. Volk T, Jahde E, Fortmeyer HP, et al. $\mathrm{pH}$ in human tumour xenografts: effect of intravenous administration of glucose. $\mathrm{Br} \mathrm{J}$ Cancer 1993;68:492-500.

37. Rollas S, Kucukguzel SG. Biological activities of hydrazone derivatives. Molecules 2007;12:1910-39.

38. Hruby M, Konak C, Ulbrich K. Polymeric micellar pH-sensitive drug delivery system for doxorubicin. J Control Release 2005;103: $137-48$.

39. Bae Y, Nishiyama N, Fukushima S, et al. Preparation and biological characterization of polymeric micelle drug carriers with intracellular $\mathrm{pH}$-triggered drug release property: tumor permeability, controlled subcellular drug distribution, and enhanced in vivo antitumor efficacy. Bioconjug Chem 2005;16:122-30.

40. Jain RK. Delivery of molecular and cellular medicine to solid tumors. Adv Drug Deliv Rev 2001;46:149-68.

41. Bae Y, Fukushima S, Harada A, Kataoka K. Design of environmentsensitive supramolecular assemblies for intracellular drug delivery: polymeric micelles that are responsive to intracellular $\mathrm{pH}$ change. Angew Chem Int Ed Engl 2003;42:4640-3.

42. Denton JJ, Turner RJ, Neier WB, et al. Antispasmodics. I. Substituted $\beta$-amino ketones. J Am Chem Soc 1949;71: 2048-50.

43. Fry EM. Observations on the Mannich reaction. J Org Chem 1945; 10:259-62.

44. Okuda T. Alkylation with Mannich bases. II. Exchange reaction of p-substituted $\beta$-dimethylaminopropiophenone with piperidine. Yakugaku Zasshi 1956;76:4-6.

45. Pathak VN, Singh RP. Studies in fluorinated Mannich bases. Part 2: synthesis and biological activity of some new 3-alkylaminopropiophenones. Die Pharmazie 1980;35:434.

46. Shoemaker RH. The NCI60 human tumour cell line anticancer drug screen. Nat Rev Cancer 2006;6:813-23.

47. Mete E, Gul HI, Cetin-Atalay R, et al. The design and cytotoxic evaluation of some 1-aryl-3-isopropylamino-1-propanone hydrochlorides towards human Huh-7 hepatoma Cells. Arch Der Pharm 2011;344:333-9.

48. Vichai V, Kirtikara K. Sulforhodamine B colorimetric assay for cytotoxicity screening. Nat Protoc 2006;1:1112-16.

49. Bradford MM. A rapid and sensitive method for the quantitation of microgram quantities of protein utilizing the principle of protein-dye binding. Anal Biochem 1976;72: 248-54. 
50. Charles AL, Guilbert AS, Bouitbir J, et al. Effect of postconditioning on mitochondrial dysfunction in experimental aortic cross-clamping. Br J Surg 2011;98:511-16.

51. Dimmock JR, Erciyas E, Kirkpatrick DL, King KM. Evaluation of some azines of aminomethylacetophenones and related quaternary ammonium compounds versus the EMT6 tumour. Die Pharmazie 1988;43:614-16.
52. Gul HI, Gul M, Vepsalainen J, et al. Cytotoxicity of some azines of acetophenone derived mono-Mannich bases against Jurkat cells. Biol Pharm Bull 2003;26:631-7.

53. Thaveau F, Zoll J, Rouyer $\mathrm{O}$, et al. Ischemic preconditioning specifically restores complexes I and II activities of the mitochondrial respiratory chain in ischemic skeletal muscle. J Vasc Surg 2007;46:541-7; discussion 547. 